\title{
Measurement and modelling of evaporation from a coastal wetland in Maputaland, South Africa
}

\author{
A. D. Clulow ${ }^{1}$, C. S. Everson ${ }^{1}$, M. G. Mengistu ${ }^{1}$, C. Jarmain ${ }^{1}$, G. P. W. Jewitt ${ }^{1}$, J. S. Price ${ }^{2}$, and P.-L. Grundling ${ }^{2,3}$ \\ ${ }^{1}$ Centre for Water Resources Research, University of KwaZulu-Natal, Private Bag X01, Scottsville, Pietermaritzburg, \\ 3209, South Africa \\ ${ }^{2}$ Department of Geography \& Environmental Management, University of Waterloo, Waterloo, Ontario, N2L 3G1, Canada \\ ${ }^{3}$ Centre of Environmental Management, University of the Free State, P.O. Box 339, Bloemfontein, 9300, South Africa
}

Correspondence to: A. D. Clulow (clulowa@ukzn.ac.za)

Received: 12 December 2011 - Published in Hydrol. Earth Syst. Sci. Discuss.: 7 February 2012

Revised: 31 July 2012 - Accepted: 20 August 2012 - Published: 10 September 2012

\begin{abstract}
The surface renewal (SR) method was used to determine the long-term (12 months) total evaporation (ET) from the Mfabeni Mire with calibration using eddy covariance during two window periods of approximately one week each. The SR method was found to be inexpensive, reliable and with low power requirements for unattended operation.

Despite maximum ET rates of up to $6.0 \mathrm{~mm} \mathrm{day}^{-1}$, the average summer (October to March) ET was lower $\left(3.2 \mathrm{~mm} \mathrm{day}^{-1}\right)$ due to early morning cloud cover that persisted until nearly midday at times. This reduced the daily available energy, and the ET was lower than expected despite the available water and high average wind speeds. In winter (May to September), there was less cloud cover but the average ET was only $1.8 \mathrm{~mm}_{\text {day }^{-1}}$ due to plant senescence. In general ET was suppressed by the inflow of humid air (low vapour pressure deficit) and the comparatively low leaf area index of the wetland vegetation. The accumulated ET over 12 months was $900 \mathrm{~mm}$. Daily ET estimates were compared to the Priestley-Taylor model results and a calibration $\alpha=1.0\left(R^{2}=0.96\right)$ was obtained for the site. A monthly crop factor $\left(K_{\mathrm{c}}\right)$ was determined for the standardised FAO-56 Penman-Monteith. However, $K_{\mathrm{c}}$ was variable in some months and should be used with caution for daily ET modelling.

These results represent not only some of the first longterm measurements of ET from a wetland in southern Africa, but also one of the few studies of actual ET in a subtropical peatland in the Southern Hemisphere. The study provides wetland ecologists and hydrologists with guidelines for the use of two internationally applied models for the estimation of wetland ET within a coastal, subtropical environment and shows that wetlands are not necessarily high water users.
\end{abstract}

\section{Introduction}

The Maputaland coastal plain (MCP) is an ecologically important area on the east coast of South Africa prone to prolonged droughts and floods (Mucina and Rutherford, 2006; Taylor et al., 2006b). It is essential in such areas to accurately determine the water balance for the effective management of the water resource. The MCP has extensive wetland areas, from which total evaporation (ET) is likely to be the dominant loss from the system (Drexler et al., 2004). Where ET estimates have been required for studies in the past, the best information has been obtained from the Water Resources of South Africa 1990 study by Midgley et al. (1994) and the published maps of the region by Schulze et al. (1997). However, this information was based on regional estimates of potential evaporation and is inadequate for detailed, long-term studies addressing water-balance, land management, environmental reserve and climate change studies.

Internationally, Souch et al. (1996) concluded that our understanding of ET and the related physical processes is not well characterized for many wetland types. Drexler et al. (2004) state that, despite the numerous methods available to quantify wetland ET, it remains insufficiently characterized due to the diversity and complexity of wetland types and no single model or measurement technique can be universally applied. Goulden et al. (2007) note the high variation in ET between wetlands and that different measurement techniques are likely to produce widely divergent measures of ET. This leaves wetland ecologists and hydrologists with some uncertainty regarding the most appropriate methods for measuring and modelling wetland ET. 
Despite the lack of a definitive conclusion above, the eddy covariance technique has probably been recognised as the most accepted method for measuring wetland ET (Souch et al., 1996; Acreman et al., 2003; Goulden et al., 2007). Recent advances have further improved the reliability of eddy covariance systems, yet there are still restrictions to their longterm deployment. The MCP study site, for example, is remote, surrounded by African wildlife, and with a high risk of theft from surrounding rural communities. An expensive eddy covariance system, requiring frequent maintenance due to high power requirements, is therefore not practical in the long term. Damage by wildlife or runaway fires and theft of batteries (or solar panels) have financial implications but are particularly costly in terms of lost data, preventing an assessment of inter-seasonal variability. To obtain long-term estimates of ET in South Africa, the current modus operandi has adopted short-term (one week) deployment of eddy covariance, in two or three different seasons over a year, to gain representative measurements of a site such as in Everson et al. (2009) and Jarmain et al. (2009). The difficulty becomes infilling these window periods, and the question of how representative a window period is of a season's ET. Drexler et al. (2004) however, found the more recently developed surface renewal (SR) to hold promise as a suitable technique for the measurement of wetland ET. In addition, the SR technique is much cheaper than an eddy covariance system, has a low power requirement, is easily maintained and can typically include multiple measurements from one system if there is a likelihood of damage (Mengistu and Savage, 2010). It therefore holds potential at sites such as the MCP, for longterm deployment to complement the short-term, window period measurements, using eddy covariance.

Meteorological models that calculate estimates of ET such as the Penman-Monteith model have gained popularity due to their relatively low data requirements and have been incorporated into numerous hydrological and crop-growth models such as CANEGRO (Inman-Bamber, 1991), ACRU (Schulze, 1995), SWB (Annandale et al., 2003) and SAPWAT (van Heerden et al., 2009) amongst others. These formulations are most suitable for uniform agricultural crops and have not been tested for many natural vegetation types and in particular wetlands with heterogeneous vegetation, including sedges and reeds often growing in saturated or flooded conditions. For instance, the way some ET models have been applied (e.g. Penman-Monteith) has resulted in some doubt in the use of published vegetation-specific parameters such as the crop factor (Drexler et al., 2004). Much of this doubt has been removed since the standardization of the Penman-Monteith formulation by the Food and Agriculture Organization (Allen et al., 1998). Despite the value in meteorological models in estimating ET, it has long been accepted that they require vegetation- or location-specific parameters that change seasonally (Monteith, 1981; Ingram, 1983; Mao et al., 2002).
There was therefore a need to apply the most appropriate and up-to-date methods to determine the long-term ET for key strategic wetlands and to use these results to verify existing meteorologically based models. This will not only reduce uncertainty, but will also provide some guidance in terms of wetland ET rates and, thus, lead to a better understanding of the processes that define the partitioning of the surface energy balance in wetlands. In this study SR was therefore applied over a period of one year (September 2009August 2010) to determine the ET from the Mfabeni Mire in the iSimangaliso Wetland Park. These results were compared to ET estimates from two well-known meteorological models, namely, the Priestley-Taylor and FAO-56 PenmanMonteith models to provide wetland ecologists and hydrologists with an indication of their suitability to ET estimation in subtropical coastal wetlands of the MCP. This work represents one of the few ET studies in a subtropical peatland of the Southern Hemisphere. It therefore provides critical new insights into the process of ET, which may differ from the commonly studied Northern Hemisphere boreal and Arctic tundra peatlands.

\section{Study sites}

The study area is located in the Eastern Shores section of the iSimangaliso Wetland Park, which was declared South Africa's first UNESCO World Heritage Site in 1999. The study area lies adjacent to Lake St. Lucia and within the St. Lucia Ramsar Site designated in 1986. The iSimangaliso Wetland Park is a premier tourist destination contributing to the economy of the surrounding communities and the town of St. Lucia (Fig. 1).

The health and future conservation of Lake St. Lucia are strongly dependent on the water level and salinity of the water within the lake, which is controlled in part by freshwater inflows (Whitfield and Taylor, 2009). The groundwater contribution to the water balance of Lake St. Lucia is negligible except in extreme prolonged drought periods when the main rivers to the west (Mkuze, Mzinene, Hluhluwe and Nyalazi) can cease to flow and groundwater and direct rainfall are the only source of freshwater for the lake (Taylor et al., 2006a). Freshwater seepage from the groundwater mound of the Embomveni ridge in the Eastern Shores area into the Nkazana and Tewate Rivers and other seepage zones along the shoreline therefore becomes the most important contribution to the lake (Bjørkenes et al., 2006; Rawlin and Kelbe, 1991). This groundwater seepage from the Eastern Shores area has significant ecological importance as it provides refuge sites where localised freshwater inflows enable many species to survive during periods of high salinity, reducing the risk of extinction and loss of biodiversity (Vrdoljak and Hart, 2007).

The Eastern Shores is bordered by the Indian Ocean to the east and Lake St. Lucia to the west (Fig. 1). High coastal dunes form a barrier to the east, and to the west the slightly 


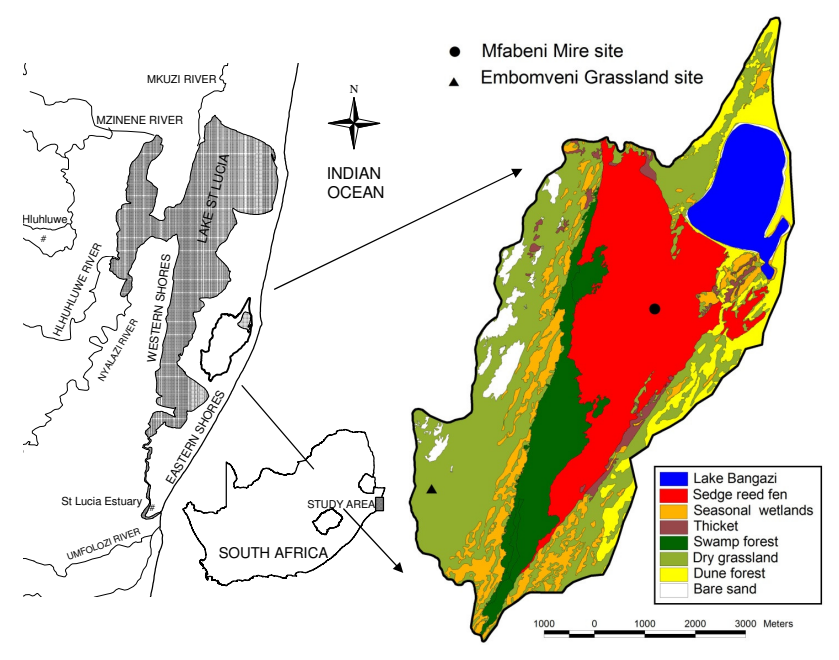

Fig. 1. The location of the Mfabeni Mire and Embomveni Dune sites on the Maputaland coastal plain. The Mfabeni Mire is represented by the sedge reed fen vegetation unit.

lower, undulating Embomveni Dunes flank Lake St. Lucia. Between these dunes lies an interdunal drainage line that forms the Mfabeni Mire. The Mire is drained by the Nkazana Stream, which feeds Lake St. Lucia and is a critical freshwater source during severe drought periods (Vrdoljak and Hart, 2007). Peat has accumulated in the Mfabeni Mire over the past $45000 \mathrm{yr}$, forming one of the largest peatlands in South Africa and one of the oldest active peatlands in the world (Grundling et al., 1998). The Mire is $8 \mathrm{~km}$ long in a northsouth direction and $3 \mathrm{~km}$ at its widest point. It has an overall extent of 1047 ha providing more than adequate fetch for the micrometeorological techniques used.

Detailed vegetation studies were completed in and around the Mfabeni Mire by Lubke et al. (1992), Sokolic (2006) and Vaeret and Sokolic (2008). The dominant species in the immediate vicinity of the Mfabeni Mire study site $\left(28^{\circ} 9.007^{\prime} \mathrm{S}, 32^{\circ} 31.492^{\prime} \mathrm{E}\right)$ were the sedges Rhynchospora holoschoenoides and Fimbristylis bivalvis, and the grasses Panicum glandulopaniculatum and Ischaemum fasciculatum. The vegetation in the vicinity of the site had an average height of $0.8 \mathrm{~m}$. The canopy cover was full, homogenous and with no areas of fully exposed peat or water. The leaf area index $(\mathrm{LAI})$ was between $\sim 1.7$ in winter and $\sim 2.8$ in summer. The plant roots had permanent access to the water table at this site.

The Mfabeni Mire is a subtropical freshwater fen surrounded by Maputaland coastal belt vegetation, which is a mixed, seasonal grassland community (Mucina and Rutherford, 2006). Therefore, for purposes of comparison, ET was also measured over a terrestrial grassland on the western Embomveni Dunes $\left(28^{\circ} 11.549^{\prime} \mathrm{S}, 32^{\circ} 28.807^{\prime} \mathrm{E}\right)$, over the same period as the Mfabeni Mire, using the same techniques. The Embomveni Dune site was $6 \mathrm{~km}$ from the measurement station in the Mfabeni Mire and therefore experienced similar climatic conditions but represented a significantly different landscape position. The dunes have an elevation of approximately $30 \mathrm{~m}$ above mean sea level. The grass roots were confined to the upper $1 \mathrm{~m}$ of the sandy soil profile and were not in contact with the water table. During the summer growing season, the grassland vegetation was therefore dependent on soil water stores and rainfall. The vegetation was mixed but the dominant plants were the grasses Trachypogon spicatus, Imperata cylindrica, the herb Helichrysum kraussii, the sedge Cyperus obtusiflorus, the succulent Crassula alba, and the shrub Parinari capensis. The average vegetation height was typically $0.4 \mathrm{~m}$ and the LAI between $\sim 0.85$ in winter and $\sim 1.2$ in summer.

The iSimangaliso Wetland Park is situated in the Indian Ocean coastal belt biome (Mucina and Rutherford, 2006). It has a subtropical climate and lies in a summer rainfall area. There is a steep rainfall gradient from east to west, and, at the coastline, the mean annual precipitation exceeds $1200 \mathrm{~mm} \mathrm{yr}^{-1}$ but only $900 \mathrm{~mm} \mathrm{yr}^{-1}$ at Fanies Island, just $10 \mathrm{~km}$ to the west. Taylor et al. (2006b) indicated that the temporal variability of the rainfall gives rise to severe wet and dry periods in Maputaland, and during this study there was a well-reported drought in the region.

\section{Materials and methods}

The shortened energy balance equation is used in evaporation studies to describe energy partitioning at the Earth's surface (Eq. 1). The "shortened" version ignores the energy associated with photosynthesis, respiration and energy stored in plant canopies, which are small when compared with the other terms (Thom, 1975). The net irradiance $\left(R_{\mathrm{n}}\right)$ equates to the sum of the sensible heat flux $(H)$, the ground heat flux $(G)$ and the latent energy flux (LE):

$R_{\mathrm{n}}=\mathrm{LE}+H+G$,

where all components except LE are measured, and the energy balance equation may be used to determine LE as the residual term in Eq. (1), which is then converted into ET (Savage et al., 2004).

Net irradiance and ground heat flux were measured at both the Mfabeni Mire and Embomveni Dune sites from October 2009 to September 2010. A net radiometer (NRLite, Kipp and Zonen, Delft, The Netherlands) was used to measure $R_{\mathrm{n}}$ at $2.0 \mathrm{~m}$ above the canopy and $G$ was measured using two soil heat flux plates (HFT-3, REBS, Seattle, WA, USA). The plates were placed at a depth of $80 \mathrm{~mm}$ below the soil surface. A system of parallel thermocouples at depths of 20 and $60 \mathrm{~mm}$ was used for measuring the soil heat stored above the soil heat flux plates, and volumetric soil water content (CS615, Campbell Scientific Inc., Logan, Utah, USA) was measured in the upper $60 \mathrm{~mm}$. At the Mfabeni Mire, the groundwater level at its highest was $0.1 \mathrm{~m}$ below the surface and, therefore, the total $G$ was determined using the 
methodology described by Tanner (1960) at both sites. The measurements were sampled every $10 \mathrm{~s}$ with a CR1000 datalogger (Campbell Scientific Inc., Logan, Utah, USA) and 30-min averages were computed.

Over the corresponding time period, $H$ was calculated using the SR technique at both the Mfabeni Mire and Embomveni Dunes. Air temperature was measured using two unshielded, type-E (chromel/constantan) fine-wire thermocouples $(76 \mu \mathrm{m}$ diameter) placed at heights of $1.00 \mathrm{~m}$ and $1.40 \mathrm{~m}$ above the ground surface. Data were recorded with a datalogger (CR3000, Campbell Scientific Inc., Logan, Utah, USA) powered by two $100 \mathrm{Ah}$ batteries and two $20 \mathrm{~W}$ solar panels. Data were recorded onto a $2 \mathrm{~GB}$ compact flash card with the capacity to store up to six weeks of high-frequency $(10 \mathrm{~Hz})$ data. The SR technique is based on the principle that an air parcel near the surface is renewed by an air parcel from above (Paw $\mathrm{U}$ et al., 1995). This process involves ramp-like structures (rapid increase and decrease of a scalar, such as air temperature in this study), which are the result of turbulent coherent structures that are known to exhibit ejections and sweeps under shear conditions (Gao et al., 1989; Raupach et al., 1996; Paw U et al., 1992). The theory of heat exchange between a surface and the atmosphere using the SR method is described in detail by Paw U et al. (1995, 2005), Snyder et al. (1996) and Mengistu and Savage (2010). The exchange of sensible heat energy between a surface and the atmosphere is expressed as

$H=\alpha \rho_{\mathrm{a}} c_{p} z \frac{a}{\tau}$,

where $\alpha$ is a weighting factor, $\rho_{\mathrm{a}}$ the density of air, $c_{p}$ the specific heat capacity of air, $z$ the measurement height, $a$ the amplitude of the air temperature ramps and $\tau$ the total ramping period.

The amplitude and the ramping period were deduced using analytical solutions of Van Atta (1977) for air temperature structure function $\left(S^{n}(r)\right)$. This is calculated for each averaging period $(2 \mathrm{~min})$ from high-frequency $(10 \mathrm{~Hz})$ airtemperature measurements using

$S^{n}(r)=\frac{1}{m-j} \sum_{i=1+j}^{m}\left(T_{i}-T_{i-j}\right)^{n}$,

where $n$ is the power of the function, $m$ the number of data points in the time interval measured at frequency $f(\mathrm{~Hz}), j$ the sample lag between data points corresponding to a time lag $r=j / f$, and $T_{i}$ is the $i$-th temperature sample. The Van Atta (1977) method then involves estimating, for each time lag, in this case 0.4 and $0.8 \mathrm{~s}$ (Mengistu and Savage, 2010), the mean value for amplitude $a$ during the time interval, by solving the following equation for the second-, third- and fifth-order roots:

$a^{3}+p a+q=0$

where $p=10 S^{2}(r)-\frac{S^{5}(r)}{S^{3}(r)}$

and

$q=1-S^{3}(r)$.

The ramp period $\tau$ is then finally calculated using

$\tau=\frac{a^{3} r}{S^{3}(r)}$.

The $2 \min H$ was calculated using QuickBASIC 4.0 software, under MS-DOS and the data then averaged to $30 \mathrm{~min}$. The weighting factor $\alpha$ is required to determine the final $H$ using the surface renewal technique (Eq. 2). It depends on the measurement height, canopy architecture (due to changes in heat exchange between the plant canopy and air parcels) and thermocouple size (due to changes in sensor response time). Once determined by calibration, it is fairly stable and does not change regardless of weather conditions unless the surface roughness changes (Snyder et al., 1996; Spano et al., 2000; Paw U et al., 2005). An extended Campbell Scientific Open Path Eddy Covariance system (Campbell Scientific Inc., Logan, Utah, USA) was therefore deployed at the Mfabeni Mire to determine the weighting factor $\alpha$ during two window periods of measurement in November 2009 and March 2010. An "Sx" style Applied Technologies, Inc. sonic anemometer (Longmont, Colorado, USA) was used at the Embomveni Dune site during the same window periods. The sensors were mounted on $3 \mathrm{~m}$ lattice towers at a height of 2.5 to $3.0 \mathrm{~m}$ above the ground level or 2.0 to $2.5 \mathrm{~m}$ above the vegetation cover. They were orientated in the direction of the prevailing wind to minimize flow distortion effects. At both sites, water vapour corrections, as proposed by Webb et al. (1980), and coordinate rotation, following Kaimal and Finnigan (1994) and Tanner and Thurtell (1969), were performed using EdiRe software (R. Clement, University of Edinburgh, UK) to determine the eddy covariance-derived $H$. The weighting factor $\alpha$ (Eq. 1) was finally obtained from the slope of the least-squares regression (forced through the origin) of the eddy covariance $H$ versus the uncalibrated surface renewal $H$ (Paw u et al., 1995). At the Mfabeni Mire and Embomveni Dunes, an $\alpha$ of 0.8 and 1.0 respectively were determined (at a measurement height of $1.0 \mathrm{~m}$ above ground surface).

Finally, LE was determined every $30 \mathrm{~min}$ as a residual in Eq. (1). The product of LE and specific heat capacity of water (Savage et al., 2004) provided the final estimate of total evaporation where $H$ was derived by surface renewal (ET $\left.{ }_{\mathrm{SR}}\right)$. During stable nighttime conditions, the analysis failed to resolve the ramp characteristic and while $R_{\mathrm{n}}<0, \mathrm{ET}_{\mathrm{SR}}$ was reduced to zero (Monteith, 1957; Baldocchi, 1994). Daily ET $_{\mathrm{SR}}$ was then used to verify the Priestley-Taylor and FAO56 Penman-Monteith models described in the results section, 
and simple linear regression was used to assess whether ET could be accurately predicted from these models. Polynomial regression quantiles (95th quantile) were fitted in GenStat (VSN International, 2011) to determine the general seasonal course of the modelled results in the Mfabeni Mire and Embomveni Dunes. Regression quantiles are useful for describing the upper "edge" of a cloud of heterogeneous data to identify the pattern of constraint imposed by the independent on the dependent variable (Cade et al., 1999). Net irradiance was used in the derivation of measured and modelled results, and therefore auto self-correlation was minimized by using independently collocated measurements.

An automatic weather station providing supporting climatic data in the Mfabeni Mire measured rainfall, air temperature and relative humidity, solar irradiance, wind speed and direction. Solar irradiance was measured using an LI200X pyranometer (LI-COR, Lincoln, Nebraska, USA). Wind speed and direction were measured using a wind sentry (Model 03002, R. M. Young, Traverse city, Michigan, USA). The rain gauge (TE525, Texas Electronics Inc., Dallas, Texas, USA) was mounted at $1.2 \mathrm{~m}$ and the remaining sensors $2 \mathrm{~m}$ above the ground. Vapour pressure deficit (VPD) was calculated from the air temperature and relative humidity sensor (HMP45C, Vaisala Inc., Helsinki, Finland) according to Savage et al. (1997). The climatic data were averaged over 30-min intervals from observations made every $10 \mathrm{~s}$ and stored on a datalogger (CR3000, Campbell Scientific Inc., Logan, Utah, USA).

To understand potential constraints to ET, volumetric soil water content was determined using CS615 time domain reflectometers (Campbell Scientific Inc., Logan, Utah, USA) at the Mfabeni Mire $(0.100 \mathrm{~m}, 0.200 \mathrm{~m}, 0.400 \mathrm{~m})$ and at the Embomveni Dunes $(0.025 \mathrm{~m}, 0.075 \mathrm{~m}, 0.125 \mathrm{~m}, 0.250 \mathrm{~m}$, $0.500 \mathrm{~m}, 1.000 \mathrm{~m})$. At the dune site, soil water potential was measured using Watermark 200 sensors (Irrometer Company, Riverside, California, USA) at the same depths. Soil water data were measured hourly and stored on a datalogger (CR10X, Campbell Scientific Inc., Logan, Utah, USA).

LAI is the surface area on one side of the leaf material $\left(\mathrm{m}^{2}\right)$ per unit area of ground $\left(\mathrm{m}^{2}\right)$. It is a biophysical property closely linked to plant ET (Allen et al., 1998). The average LAI of the vegetation at the Mfabeni Mire and Embomveni Dunes was measured at monthly intervals across each site using an LAI-2000 (LI-COR Inc., Lincoln, Nebraska, USA).

\section{Results}

\subsection{Weather conditions during the study period}

Over the study period, most of the rainfall occurred during the summer months from October through to March, although there was some rainfall experienced in winter (May to August) associated with frontal conditions (Fig. 2). At the research site in the Mfabeni Mire, the precipitation over the 12-month measurement period was $650 \mathrm{~mm}$ (Fig. 2). This was significantly below the annual average $(1200 \mathrm{~mm})$ but in agreement with the well-reported drought in the region. The groundwater level at the beginning (October 2009) of the study period at Mfabeni was $0.1 \mathrm{~m}$ below the surface and by the end of August 2010 was $0.3 \mathrm{~m}$ below the surface, confirming the prevailing drought conditions. In normal rainfall years, Mfabeni Mire is often flooded in summer with water depths of $\sim 0.3 \mathrm{~m}$.

Daily solar radiant density fluctuated seasonally, peaking at $12 \mathrm{MJ} \mathrm{m}^{-2}$ in winter and $27 \mathrm{MJ} \mathrm{m}^{-2}$ in summer (Fig. 2), but was more variable in summer due to cloud cover, which was particularly prevalent during the mornings until 11:00 a.m. LT. Maximum temperatures in the Mfabeni Mire were frequently above $30^{\circ} \mathrm{C}$ in summer and generally below $30^{\circ} \mathrm{C}$ in winter. The average daily minimum temperature was $20^{\circ} \mathrm{C}$ in summer and rarely below $5^{\circ} \mathrm{C}$ in winter, although, on 17 June 2010 , the temperature dropped to $-1.2^{\circ} \mathrm{C}$. The humid coastal conditions are best described by the average daytime $\left(R_{\mathrm{n}}>0\right)$ VPD of $0.79 \mathrm{kPa}$ indicating a low atmospheric evaporative demand generally. The monthly average daytime VPD was between $0.56 \mathrm{kPa}$ and $0.96 \mathrm{kPa}$ (Fig. 3) with October experiencing the lowest and February the highest VPD. The average daytime $\left(R_{\mathrm{n}}>0\right)$ wind speed was $4 \mathrm{~m} \mathrm{~s}^{-1}$ (Fig. 3). The highest monthly average was measured in October $\left(5.4 \mathrm{~m} \mathrm{~s}^{-1}\right)$ and the lowest in May $\left(3.2 \mathrm{~m} \mathrm{~s}^{-1}\right)$.

Fires are a common occurrence in South African wetlands (Kotze and Breen, 2000). A runaway fire burned through the Mfabeni Mire just before measurements commenced in September 2009. It spread from dry peat that smoldered for weeks in the northeast corner of the Mfabeni Mire and was rekindled by a change in wind direction. Despite high wind speeds during the fire, the burn was patchy due to low fuel load densities, and some of the actively growing vegetation such as the reeds and sedges were undamaged. The burn however, provided an opportunity to investigate the ET directly after a fire, followed by natural spring re-growth.

Albedo (ratio of reflected irradiance from the surface to incident irradiance upon it) increased after the fire in September 2009 from 0.10 to 0.22 in April 2010 due to vegetative re-growth (Fig. 4) and then gradually decreased again to approximately 0.17 due to plant senescence and winter conditions.

\subsection{Measured energy balance and total evaporation}

Net irradiance at the Mfabeni Mire in summer (up to $800 \mathrm{~W} \mathrm{~m}^{-2}$ ) was variable due to intermittent cloud cover (Fig. 5a). Cloudy mornings, with some clearing between 10:00 and 11:00 were common. During winter, there was noticeably less variation in $R_{\mathrm{n}}$ due to the dominance of clear skies (Fig. 5b). For example, in August 2010, four of the days $(18,21,22$ and 23) showed complete cloudless conditions, which were never observed during the summer period. 


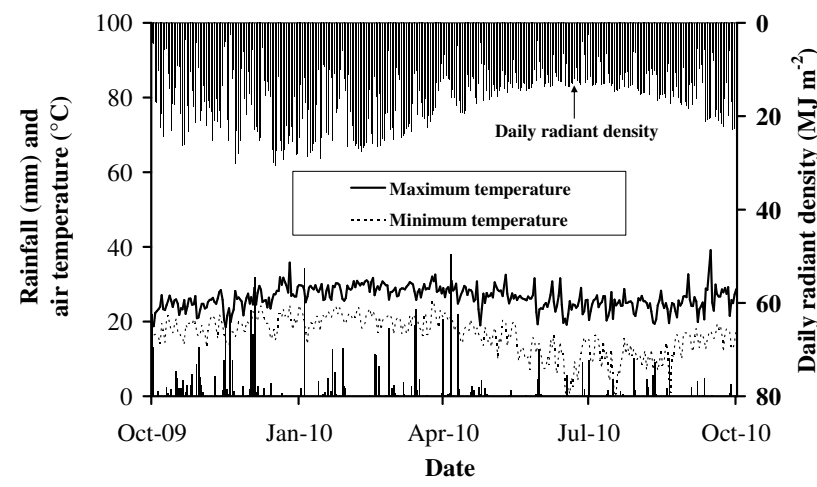

Fig. 2. Climatic conditions at the Mfabeni Mire including maximum and minimum air temperature $\left({ }^{\circ} \mathrm{C}\right)$, rainfall $(\mathrm{mm})$ and daily solar radiant density $\left(\mathrm{MJ} \mathrm{m}^{-2}\right)$ from October 2009 to September 2010.

At the Embomveni Dunes, the peak daily $R_{\mathrm{n}}$ in summer (Fig. 5c) was $\sim 100 \mathrm{~W} \mathrm{~m}^{-2}$ lower than at the Mfabeni Mire but in winter they were similar. This is a function of the albedo and indicated that there was more irradiance reflected from the Dunes than the Mire in summer. Where exposed, the dark surface of the peat at the Mfabeni Mire was in contrast to the off-white sand of the Embomveni Dunes. However, plant senescence in winter reduced the difference in the reflected irradiance between the sites. This is shown by the slope of the linear regression of $R_{\mathrm{n}}$ at the Mfabeni Mire and on the $R_{\mathrm{n}}$ at the Embomveni Dunes of 0.84 in summer (Fig. 6a), whereas in winter the slope was 0.97 (Fig. 6b). In addition, the lower co-efficient of determination during summer $\left(R^{2}=0.90\right)$ over winter $\left(R^{2}=0.99\right)$ supports the cloudiness noted in the paper, which, despite the close proximity of the sites $(6 \mathrm{~km})$, introduced differences in half hourly solar radiation results between the sites (Fig. $6 \mathrm{a}$ and $\mathrm{b}$ ).

There was a marked dominance of $H$ over LE at the Embomveni Dunes $(\beta>1)$ in summer and winter (Table 1; Fig. 5c and d). The exception was when rainfall increased the soil water content. For example, $12 \mathrm{~mm}$ of rain on 19 and 20 August 2010 increased the near-surface volumetric soil water content from $6.2 \%$ to $8.7 \%$. On the 21 and 22 August, the LE was similar to the $H$ but, by 23 August, ET had depleted the soil water to $7.0 \%$ and $H$ dominated the energy balance again. This showed the dependence of the grassland $\mathrm{ET}_{\mathrm{SR}}$ on soil water and identified it as a limiting factor for growth.

There was a shift in the distribution of the energy balance at the Mfabeni Mire between summer and winter (Table 1). At the Mfabeni Mire, in summer, the ratio LE : $R_{\mathrm{n}}(0.61)$ was almost twice $H: R_{\mathrm{n}}(0.31)$, while $G: R_{\mathrm{n}}$ made up the remainder (0.08). The pattern shifted in winter to an equal split between LE: $R_{\mathrm{n}}$ and $H: R_{\mathrm{n}}(0.46)$, while $G: R_{\mathrm{n}}$ was again 0.08 . The reduced dominance of LE: $R_{\mathrm{n}}$ was likely due to plant senescence in winter and was typical of a surface with full canopy cover. At the Embomveni Dunes, there was little

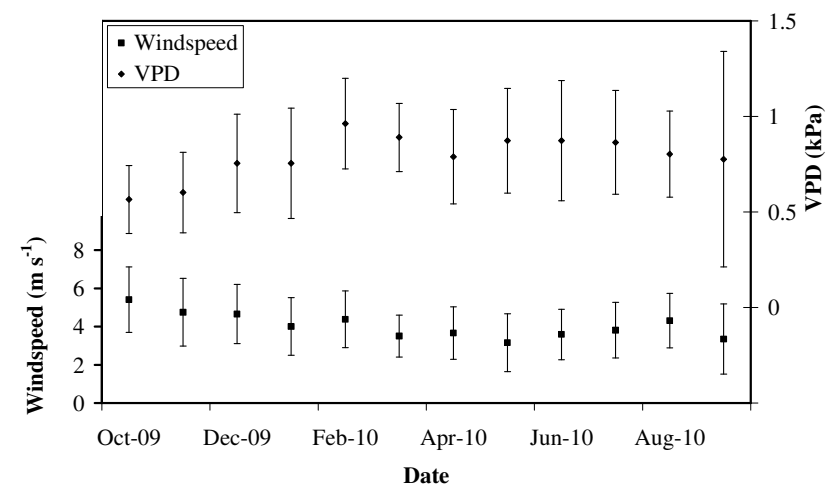

Fig. 3. Monthly average wind speed and VPD (with standard deviation error bars) at the Mfabeni Mire from October 2009 to September 2010 .

change in the energy partitioning between seasons. This indicated that the limiting factors controlling the partitioning of the energy balance remained consistent between seasons. The exception was after rainfall at the Embomveni Dunes where a change in water availability altered the partitioning of the energy balance as discussed above. At both sites there was little change in the ratio $G: R_{\mathrm{n}}$ between seasons as the reduced LAI in winter (described above) was likely offset by a lower sun angle.

The ET $\mathrm{SR}_{\mathrm{SR}}$ at the Mfabeni Mire varied seasonally (Fig. 7). Intermittent cloud cover during the summer period (October to March) resulted in large daily fluctuations in $\mathrm{ET}_{\mathrm{SR}}$. This was also evident in the high variability of $R_{\mathrm{n}}$ in summer in comparison to the winter period, which the meteorological data (Fig. 2) showed to be characteristic of the coastal weather patterns for the area. In the Mfabeni Mire, the average summer $\mathrm{ET}_{\mathrm{SR}}$ was $3.2 \mathrm{~mm}_{\text {day }^{-1}}\left(\sigma=1.4 \mathrm{~mm} \mathrm{day}^{-1}\right)$. The fitted $95 \%$ regression quantile $(p<0.001)$ indicated potential maximum daily rates in summer to be approximately $6.0 \mathrm{~mm} \mathrm{day}^{-1}$. During the winter months (April to September), the average daily ET $\mathrm{SR}_{\mathrm{SR}}$ was $1.8 \mathrm{~mm} \mathrm{day}^{-1}(\sigma=$ $0.8 \mathrm{~mm} \mathrm{day}^{-1}$ ) with an estimated potential maximum around the winter solstice of $1.3 \mathrm{~mm}_{\text {day }}{ }^{-1}$. The accumulated $\mathrm{ET}_{\mathrm{SR}}$ over 12 months was $900 \mathrm{~mm}$ (Table 2), of which $64 \%$ occurred in the summer months (October to March).

At the Embomveni Dune site (Fig. 7), as with the Mfabeni Mire, there were many cloudy days in summer. The average summer $\mathrm{ET}_{\mathrm{SR}}$ (October to March) was $1.7 \mathrm{~mm}_{\text {day }}{ }^{-1}$ $\left(\sigma=0.8 \mathrm{~mm} \mathrm{day}^{-1}\right)$ with the maximum rate estimated by the $95 \%$ regression quantile of approximately $3.0 \mathrm{~mm} \mathrm{day}^{-1}$. The average daily $\mathrm{ET}_{\mathrm{SR}}$ during the winter months (April to August) was $1.0 \mathrm{~mm} \mathrm{day}^{-1}\left(\sigma=0.8 \mathrm{~mm} \mathrm{day}^{-1}\right)$ with an estimated maximum around the winter solstice of $1.2 \mathrm{~mm} \mathrm{day}^{-1}$. The accumulated $\mathrm{ET}_{\mathrm{SR}}$ over 12 months was $478 \mathrm{~mm}$ (Table 2), of which approximately $63 \%$ occurred in the summer months (October to March). 


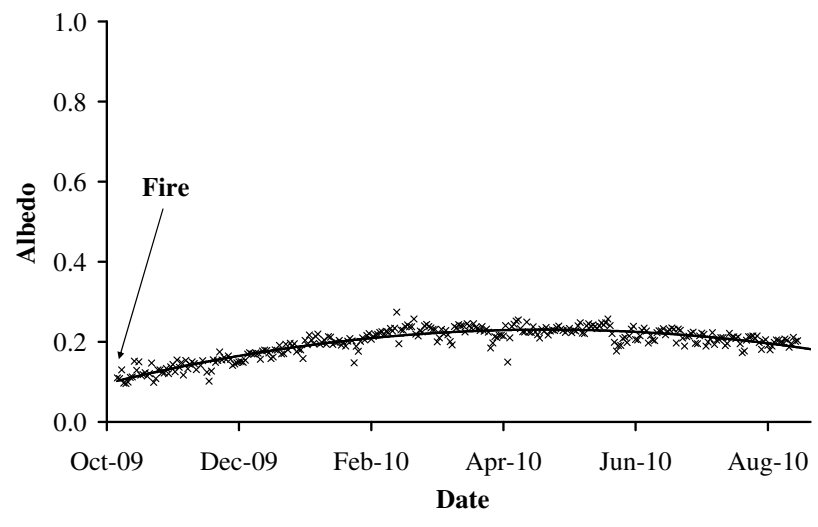

Fig. 4. The change in albedo of the Mfabeni Mire following the recovery of vegetation after a fire in September 2009.

Despite the close proximity of the two sites $(6 \mathrm{~km}), \mathrm{ET}_{\mathrm{SR}}$ at the Mfabeni Mire $(900 \mathrm{~mm})$ was almost double the $\mathrm{ET}_{\mathrm{SR}}$ at the Embomveni Dune site $(478 \mathrm{~mm})$. This difference was due to the freely available water at the Mfabeni Mire and the different vegetation types found between the sites. The dominant limitations to transpiration and surface evaporation at the Mfabeni Mire were likely to have been available energy, low atmospheric demand (noted above) and some stomatal control (mainly of the grasses) due to plant senescence in winter. The $\mathrm{ET}_{\mathrm{SR}}$ at the Embomveni Dunes was limited by soil water content and the low water-use requirements of the dune vegetation, an adaptation to survive prolonged dry conditions. Even for brief periods after rainfall when soil water was not limiting, the daily $\mathrm{ET}_{\mathrm{SR}}$ was still lower than the Mfabeni Mire. However, soil water availability was generally low with volumetric water content of $\sim 6 \%$ and frequently below $-800 \mathrm{kPa}$ at a depth of $0.075 \mathrm{~m}$ (measured continuously but not shown).

The SR method was found to be reliable, easy to operate in the field and suitable for long-term, unattended use over wetlands with calibration using eddy covariance. However, the fine-wire thermocouples are fragile and easily broken by animals, hail or contact with fast growing vegetation, and at least one backup thermocouple was used.

\subsection{Modelling of total evaporation}

Evaporation measurement is complex and in most studies of wetland hydrology is modelled using weather data collected from a nearby automatic weather station. Two methods used widely for wetland applications are the FAO-56 PenmanMonteith method (Allen et al., 1998) and the Priestley-Taylor method (Priestley and Taylor, 1972). These models are relatively simple and suitable for use by hydrologists or wetland ecologists to determine wetland ET. They are also well suited to wetland applications as water availability does not limit transpiration.

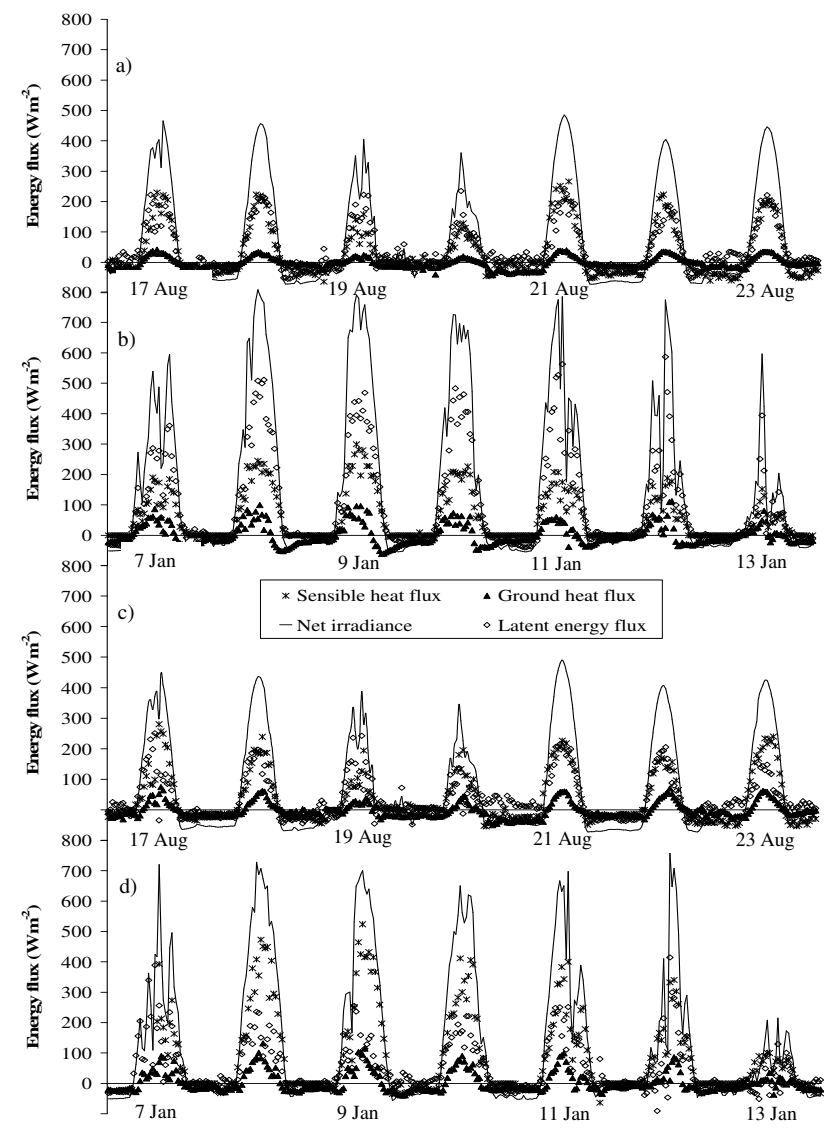

Fig. 5. Diurnal energy fluxes at Mfabeni Mire on (a) 17 to $23 \mathrm{Au}-$ gust 2009 and (b) 7 to 13 January 2010 and on corresponding days at the Embomveni Dunes in (c) August 2009 and (d) January 2010.

FAO-56 Penman-Monteith: the original Penman model (Penman, 1948) is frequently cited and was a significant contribution to evaporation modelling. It was improved by Monteith (1965) by incorporating surface and aerodynamic resistance functions and was widely used in this form as the Penman-Monteith equation. It is still commonly applied but is highly data intensive (Mao et al., 2002; Drexler et al., 2004). The equation was later standardised by the Food and Agriculture Organisation (Allen et al., 1998) into a form known as the FAO-56 Penman-Monteith model. The standardisation includes the definition of a reference crop as "a hypothetical crop with an assumed height of $0.12 \mathrm{~m}$ having a surface resistance of $70 \mathrm{~m} \mathrm{~s}^{-1}$ and an albedo of 0.23 , closely resembling the evaporation of an extensive surface of green grass of uniform height, actively growing and adequately watered" (Allen et al., 1998).

The FAO-56 Penman-Monteith model provides an estimate of ET from a hypothetical grass reference surface $\left(\mathrm{ET}_{\mathrm{r}}\right)$. It can be universally applied as it provides a standard to which ET, at different times of the year or in other regions, can be compared and to which the ET from other crops can be related. It is used internationally to estimate crop ET using the crop factor $\left(K_{\mathrm{c}}\right)$ approach in the form: 
Table 1. Distribution of the average daily energy balance as fractions of $R_{\mathrm{n}}$, as well as the Bowen ratio $(\beta)$, at the Mfabeni Mire and Embomveni Dune sites.

\begin{tabular}{lrrrrrrrrrr}
\hline \multirow{2}{*}{ Site } & \multicolumn{4}{c}{ Summer } & & \multicolumn{5}{c}{ Winter } \\
\cline { 2 - 4 } \cline { 8 - 11 } & LE $: R_{\mathrm{n}}$ & $H: R_{\mathrm{n}}$ & $G: R_{\mathrm{n}}$ & $\beta$ & & LE $: R_{\mathrm{n}}$ & $H: R_{\mathrm{n}}$ & $G: R_{\mathrm{n}}$ & $\beta$ \\
\hline Mfabeni Mire & 0.61 & 0.31 & 0.08 & 0.51 & & 0.46 & 0.46 & 0.08 & 1.00 \\
Embomveni Dunes & 0.36 & 0.55 & 0.09 & 1.53 & & 0.37 & 0.53 & 0.10 & 1.43 \\
\hline
\end{tabular}
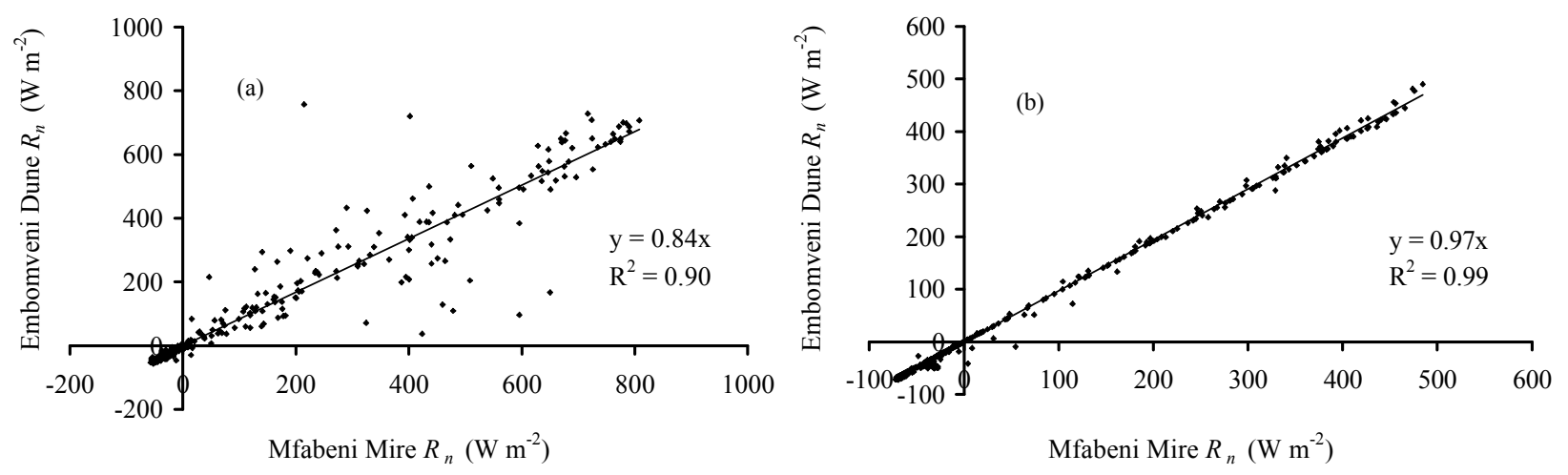

Fig. 6. The difference in summer (a) and winter (b) net radiation $R_{\mathrm{n}}$ (half hourly) between the Mfabeni Mire and Embomveni Dune sites shown by the slope of the least squares linear regression.

Table 2. Summary of seasonal and annual total evaporation derived using a surface renewal system to calculate the sensible heat flux.

\begin{tabular}{llll}
\hline Site & Summer $(\mathrm{mm})$ & Winter $(\mathrm{mm})$ & Total $(\mathrm{mm})$ \\
\hline Mfabeni Mire & $575(\sigma=1.4)$ & $325(\sigma=0.8)$ & $900(\sigma=1.4)$ \\
Embomveni Dunes & $303(\sigma=0.8)$ & $175(\sigma=0.4)$ & $478(\sigma=0.7)$ \\
\hline
\end{tabular}

$K_{\mathrm{c}}=\frac{\mathrm{ET}}{\mathrm{ET}_{\mathrm{r}}}$

where the crop is not water-stressed. In Allen et al. (1998), numerous values of $K_{\mathrm{c}}$ have been compiled for different vegetation types and the different stages in crop development.

The $\mathrm{ET}_{\mathrm{r}}$ was calculated hourly and summed each day. The daily results of $\mathrm{ET}_{\mathrm{r}}$ (Fig. 8) reflected a similar seasonal trend to that shown by the $\mathrm{ET}_{\mathrm{SR}}$ (Fig. 7) at the Mfabeni Mire. The standard deviation $(\sigma)$ in summer was higher $(1.3 \mathrm{~mm})$ than in winter $(0.7 \mathrm{~mm})$. Monthly $K_{\mathrm{c}}$ averages (Fig. 9$)$ reflect the need to accommodate seasonal changes in $K_{\mathrm{c}}$ at times. The monthly $95 \%$ confidence intervals indicate a higher variability of daily $K_{\mathrm{c}}$ from June to January compared to February through to May. From October to January, there was no significant difference between mean monthly $K_{\mathrm{c}}$, and a single mean over this period would be suitable. However, from February to September, all but two of the monthly $K_{\mathrm{c}} \mathrm{s}$ are significantly different and a monthly $K_{\mathrm{c}}$ should be used over these months. Over the 12 months of measurement, the average $K_{\mathrm{c}}$ was 0.80 indicating that the $\mathrm{ET}_{\mathrm{SR}}$ was on

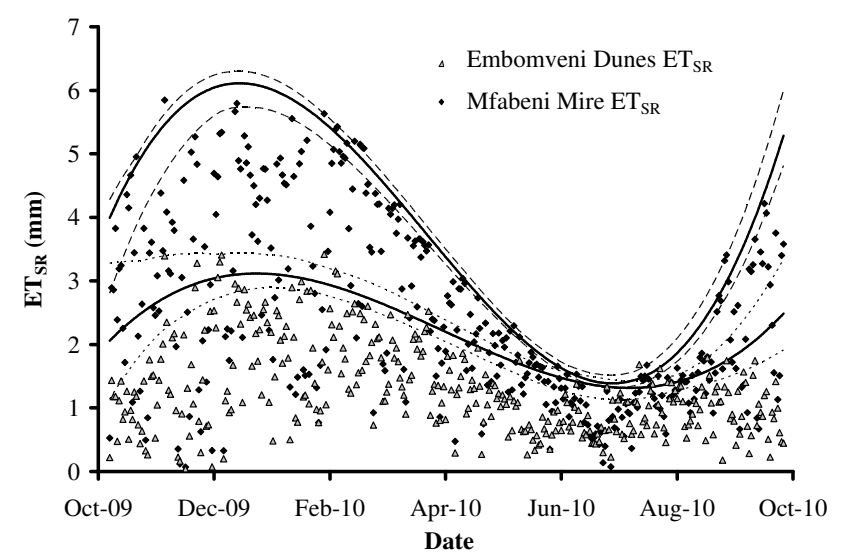

Fig. 7. Daily total evaporation at the Mfabeni Mire (upper line) and Embomveni Dunes (lower line) from October 2009 to September 2010 using the surface renewal technique. Solid lines represent fitted $95 \%$ regression quantiles and dashed lines their $95 \%$ confidence intervals.

average $20 \%$ less than $\mathrm{ET}_{\mathrm{r}}$. This $K_{\mathrm{c}}$ result was low for a wetland, particularly considering the freely available water in the Mfabeni Mire. Although the linear regression of $\mathrm{ET}_{\mathrm{SR}}$ on $\mathrm{ET}_{\mathrm{r}}$ was significant $\left(F_{1,355}=1640, p<0.001\right)$ and accounted for $82 \%$ of the variation in $\mathrm{ET}_{\mathrm{SR}}$, residual variation about the regression was not constant (heteroscedastic), even under various data transformations. This suggests that the crop factor approach was not suited to estimating ET for the Mfabeni Mire. 


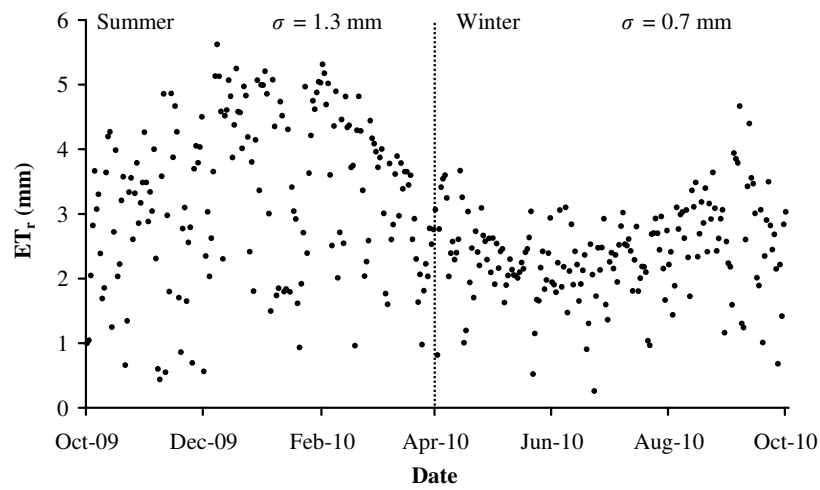

Fig. 8. The short grass reference evaporation $\left(\mathrm{ET}_{\mathrm{r}}\right)$ from October 2009 to September 2010 in the Mfabeni Mire.

Priestley-Taylor: the Priestley-Taylor model (Priestley and Taylor, 1972) is a simplified version of the more theoretical Penman model. The aerodynamic terms of the Penman model are replaced by an empirical and constant $\alpha$ known as the advective term. It is reasoned that, as an air mass moves over an expansive, short, well-watered canopy, ET would eventually reach a rate of equilibrium when the air is saturated and the actual rate of ET would be equal to the Penman rate of potential evapotranspiration. This is referred to as equilibrium evaporation $\left(\mathrm{ET}_{\mathrm{EQ}}\right)$. Under these conditions, the aerodynamic term of the Penman equation approaches zero and irradiance dominates. The Priestley-Taylor model is therefore commonly used to estimate evaporation from wetlands (Price, 1992; Souch et al., 1996; Mao et al., 2002) and was applied in this study in the form described by Savage et al. (1997).

At the Mfabeni Mire, $\operatorname{ET}_{\mathrm{EQ}}(\alpha=1$, Fig. 10) reflected the seasonality observed in $\mathrm{ET}_{\mathrm{SR}}$ (Fig. 7). The fitted $95 \%$ regression quantile $(p<0.001)$ indicates maximum rates on clear days. In summer the maximum rates were higher $\left(6.0 \mathrm{~mm} \mathrm{day}^{-1}\right)$ but more variable $(\sigma=$ $\left.1.5 \mathrm{~mm} \mathrm{day}^{-1}\right)$ and, in winter, lower $\left(1.7 \mathrm{~mm} \mathrm{day}^{-1}\right)$ and less variable $\left(0.8 \mathrm{~mm} \mathrm{day}^{-1}\right)$. A linear regression of $\mathrm{ET}_{\mathrm{SR}}$ on $\mathrm{ET}_{\mathrm{EQ}}\left(F_{1,355}=7553, p<0.001\right)$ over the 12 months of measurement indicated that ET can be accurately predicted $\left(R^{2}=0.96\right)$ by the Priestley-Taylor equilibrium model at the Mfabeni Mire. The Priestley-Taylor $\alpha$ is represented by the slope of the linear regression in Fig. 11 and is equal to 1 (intercept of -0.3 ).

The dry conditions of the Embomveni Dune site violate the "well-watered" assumptions of the Priestley-Taylor model; however, it was used at this site for comparison with the Mfabeni Mire. As with the Mfabeni Mire, the $\mathrm{ET}_{\mathrm{EQ}}$ at the Embomveni Dune site reflected the seasonality of $\mathrm{ET}_{\mathrm{SR}}$ with summertime highs of $5 \mathrm{~mm} \mathrm{day}^{-1}\left(\sigma=0.8 \mathrm{~mm} \mathrm{day}^{-1}\right)$ and wintertime lows of $1.8 \mathrm{~mm} \mathrm{day}^{-1}\left(\sigma=0.4 \mathrm{~mm} \mathrm{day}^{-1}\right)$. An acceptable linear regression of $\mathrm{ET}_{\mathrm{SR}}$ on $\mathrm{ET}_{\mathrm{EQ}}$ was found with square-root transformed data to ensure a constant and

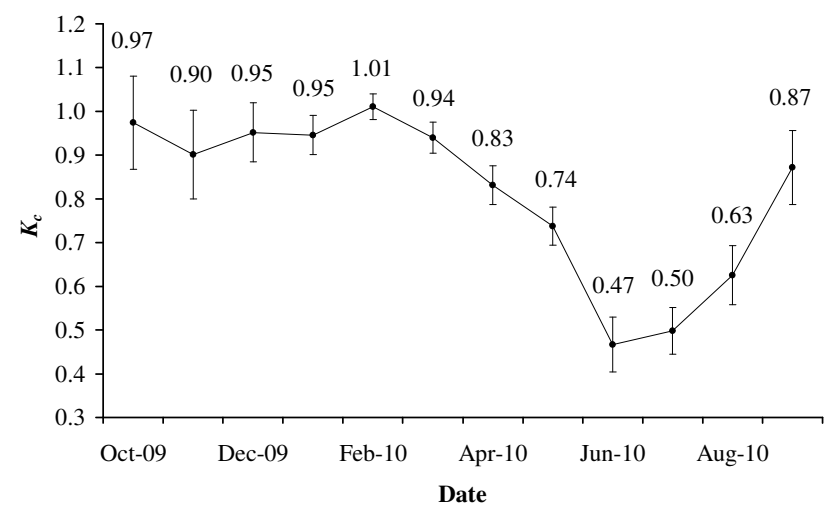

Fig. 9. Mean monthly crop factor $\left(K_{\mathrm{c}}\right)$ for the Mfabeni Mire from October 2009 to September 2010 with $95 \%$ confidence intervals.

approximately normally distributed residual. However, the confidence with which $\mathrm{ET}_{\mathrm{EQ}}$ can be used to estimate $\mathrm{ET}_{\mathrm{SR}}$ was lower $\left(R^{2}=0.71\right)$ than at the Mfabeni Mire $\left(R^{2}=\right.$ 0.96). In summer for example, the $95 \%$ regression quantile of $\mathrm{ET}_{\mathrm{SR}}$ was only $3.0 \mathrm{~mm} \mathrm{day}^{-1}$, whereas $\mathrm{ET}_{\mathrm{EQ}}$ was $5 \mathrm{~mm}$ day $^{-1}$. This indicated that a severe constraint was imposed by low soil water availability (measured but not shown). For example, on the days of 21 and 22 August (following $12 \mathrm{~mm}$ of rain on 19 and 20 August), the near-surface volumetric water content increased from $6.2 \%$ to $8.7 \%$ and the Priestley-Taylor $\alpha$ was 0.8 and 0.81 respectively. However by the 23 August, the surface soil water was depleted to $7.0 \%$ and the Priestley-Taylor $\alpha$ was restricted to 0.52 by the soil water limitation.

\section{Discussion}

The SR method, used to estimate $H$ in this study, was found to be reliable for long-term, unattended use over the Mfabeni Mire with periodic calibration using eddy covariance. Once determined, a re-calibration is only required if there are significant changes in the vegetation canopy (Snyder et al., 1996; Spano et al., 2000; Paw U et al., 2005). Further advantages found to be significant in this study included the relatively low cost of the system, the low power consumption and the simple and basic maintenance requirements in comparison to alternative methods available for estimating $H$. This was particularly important as it reduced the cost and time resources required for field visits, as the site was remote and the study was long-term. In addition, Drexler et al. (2004) comment that the SR method is less dependent on fetch than other methods (eddy covariance). Therefore, in wetlands with complex surfaces with areas of open water, soil and vegetation, the number of measurements can be replicated at a low cost by including additional fine-wire thermocouples offering a better spatial representation of ET. 


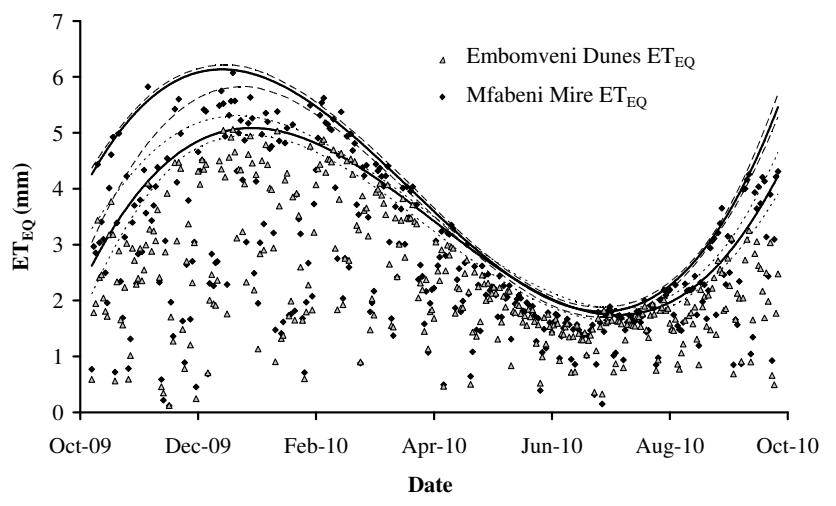

Fig. 10. The equilibrium evaporation $\left(E T_{E Q}\right)$ from October 2009 to September 2010 at the Mfabeni Mire (upper line) and Embomveni Dunes (lower line). Solid lines represent fitted $95 \%$ regression quantiles and dashed lines their $95 \%$ confidence intervals.

The site-specific calibration required by the SR method is however a disadvantage as an independent measure of $H$ is required over a suitable calibration period. In addition, the SR method was introduced by Paw U and Brunet (1991) and is still relatively new in terms of measurement systems. As a result there are no complete SR systems available commercially as there are with other methods (eddy covariance). This introduces a significant barrier for wetland hydrologists or ecologists as expertise in logger programming, data processing and an understanding of micrometeorological measurement are required. The fine-wire thermocouples $(76 \mu \mathrm{m}$ diameter), although not prohibitively expensive, are fragile and breakage can result in data loss if backup thermocouples are not installed.

Despite improvements to measurement techniques and the dominant role of ET in wetland water balances, there are few studies in southern Africa with actual measurements of ET from wetlands. Wetland ET has been estimated in the Ntabamhlope research catchment in the foothills of the Drakensberg using diurnal fluctuations in the water table levels (Smithers et al., 1995) with significant residuals and deficiencies identified in the technique. Also at Ntabamhlope, an evaporimeter was used together with the Penman (1948) method and the complementary relationship concept of Bouchet (1963), but problems with instrumentation drift compromised the results (Chapman, 1990). The Nylsvlei floodplain is a seasonal wetland of the semi-arid Limpopo Province in the north of South Africa. Total evaporation was estimated in the Nylsvlei wetland using a combination of meteorological models, pan evaporation and a few days of energy balance measurements (ignoring sensible heat flux) to derive monthly means of ET (Birkhead et al., 2007).

A more comprehensive wetland ET study in South Africa was performed by Dye et al. (2008) near Orkney $\left(27.02^{\circ} \mathrm{S}, 26.68^{\circ} \mathrm{E}\right)$ in the dry Highveld grassland bioregion of central South Africa. The Bowen ratio

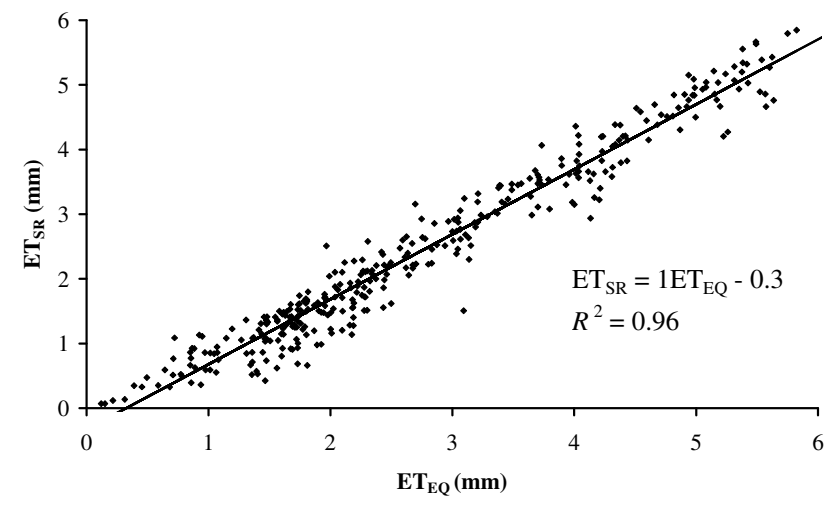

Fig. 11. The advective term $(\alpha)$ at the Mfabeni Mire determined as the slope of the least squares linear regression of $\mathrm{ET}_{\mathrm{EQ}} \mathrm{vs}$. $\mathrm{ET}_{\mathrm{SR}}$ from October 2009 to September 2010.

technique and eddy covariance were used intermittently over a Phragmites communis-dominated marsh over one year. The ET in summer in the marsh peaked at $6.0 \mathrm{~mm} \mathrm{day}^{-1} \quad\left(\right.$ Mfabeni $\left.=6.0 \mathrm{~mm} \mathrm{day}^{-1}\right)$ and averaged approximately $3 \mathrm{~mm} \mathrm{day}^{-1} \quad\left(\right.$ Mfabeni $\left.=3.2 \mathrm{~mm} \mathrm{day}^{-1}\right)$. Around the winter solstice, peak rates of $1.6 \mathrm{~mm}^{-1} \mathrm{yy}^{-1}$ $\left(\right.$ Mfabeni $\left.=1.3 \mathrm{~mm} \mathrm{day}^{-1}\right)$ were measured. Dye et al. (2008) also noted the summertime variation in daily ET rates depended on cloud and humidity. These results from Orkney compared favourably with the results from Mfabeni and indicated that, despite the geographically distinct location and altitude, the ET estimates were similar.

Also inland but further to the north, ET was measured in a riparian area of the Sabie River in the Kruger National Park, South Africa (Everson et al., 2001). The Bowen ratio technique was applied over a Phragmites mauritianusdominated marsh in a riparian wetland. Maximum ET rates were $9 \mathrm{~mm} \mathrm{day}^{-1}$ in summer and $4 \mathrm{mmday}^{-1}$ in winter. These rates are higher than at the Mfabeni Mire due to the higher available energy, but most significantly the daily average VPDs were higher (mostly between 1 and $3 \mathrm{kPa}$ ) and therefore the sites are not comparable.

The $\mathrm{ET}_{\mathrm{SR}}$ results from the Embomveni Dunes (terrestrial grassland) serve as an interesting contrast to the Mfabeni Mire $\mathrm{ET}_{\mathrm{SR}}$. The 12-month-accumulated ET $\mathrm{SR}_{\mathrm{SR}}$ at the Mfabeni Mire was $900 \mathrm{~mm}$ in contrast to $478 \mathrm{~mm}$ at the Embomveni Dune site. The soil water content at the grassland was low $(\sim$ $6 \%$ volumetric and frequently below $-800 \mathrm{kPa}$ at a depth of $0.075 \mathrm{~m}$ ) during the measurement period due to the prevailing drought conditions. The ET $\mathrm{SR}_{\mathrm{SR}}$ at the Embomveni Dunes was therefore limited by soil water availability rather than energy. A similar result was observed by Jacobs et al. (2002) in a wet prairie under drought conditions in Central Florida, USA. They found that the fraction of available energy used in the evaporation and transpiration of water depended on soil water content and that a two-stage model with a reduction coefficient under dry conditions was appropriate. The soil water 
content in the Mfabeni Mire was by comparison much higher (>85\%), and the $\mathrm{ET}_{\mathrm{SR}}$ was energy limited.

In South Africa, two comparative long-term studies of ET over grasslands have been performed. Everson et al. (1998) estimated ET over Themeda triandra grasslands of the Drakensberg escarpment near Cathedral Peak $\left(28.95^{\circ} \mathrm{S}, 29.20^{\circ} \mathrm{E}\right)$. Cathedral Peak lies approximately $250 \mathrm{~km}$ inland of the coast with altitudes of $2000 \mathrm{~m}$ and falls within the grassland biome. They found maximum daily ET to be as high as $7 \mathrm{mmday}^{-1}$ in summer $\left(\right.$ Embomveni $=3.0 \mathrm{~mm} \mathrm{day}^{-1}$ ) and $<1 \mathrm{~mm} \mathrm{day}^{-1}$ in winter (Embomveni $<1.2 \mathrm{~mm} \mathrm{day}^{-1}$ ). The high summer rates of the Drakensberg are likely to contrast with the Embomveni Dunes for a number of reasons. The high summer rainfall (long-term average $=1299 \mathrm{~mm}$ ) of the Drakensberg area (compared to $650 \mathrm{~mm}$ measured in the Mfabeni Mire) sustained an adequate soil water content (generally $>43 \%$ and $<80 \mathrm{kPa}$ ) in comparison to the rapidly draining drier soils of the Embomveni Dune site (generally $<7 \%$ and $>200 \mathrm{kPa}$ ), which limited ET. In addition, the summer VPD of the Drakensberg (Everson et al., 2012) is higher (mostly between 1.5 and $2.5 \mathrm{kPa}$ ) than at the Embomveni Dunes (mostly between 0.5 to $1.5 \mathrm{kPa}$ ). The lower atmospheric demand together with the lower soil water content explains the lower summertime ET rates of the Embomveni Dunes and brings into question a quantitative comparison between these sites. The second study was performed by Savage et al. (2004) in the KwaZuluNatal Midlands near Pietermaritzburg $\left(24.63^{\circ} \mathrm{S}, 30.43^{\circ} \mathrm{E}\right)$, approximately $100 \mathrm{~km}$ from the coast in a mixed grassland community during a dry period. They reported average daily summer ET rates to be approximately $3 \mathrm{~mm} \mathrm{day}^{-1}$ and daily winter ET $1 \mathrm{~mm} \mathrm{day}^{-1}$. These results are closer to the $\mathrm{ET}_{\mathrm{SR}}$ in the Embomveni Dune site possibly due to the similar drought conditions and a water-limiting environment reported during their study.

Internationally, there are no comparable ET studies in the Southern Hemisphere to those at the Mfabeni Mire. In Australia, the subtropical wetland studies focus on water treatment wetlands where the "clothes line effect" is noted (Headley et al., 2012) and in South America the focus is forest wetlands (Fujieda et al., 1997). In the Northern Hemisphere however, the Florida (USA) Everglades wetland region has been studied intensively and the results at Mfabeni Mire can be compared with studies by Mao et al. (2002) and Abtew (1996) who found ET rates slightly higher than those measured at the Mfabeni Mire over cattail and saw-grass vegetation. Abtew (1996) found annual average rates of ET over mixed marsh of $3.5 \mathrm{~mm} \mathrm{day}^{-1}\left(\right.$ Mfabeni $\left.=2.5 \mathrm{~mm} \mathrm{day}^{-1}\right)$. Mao et al. (2002) measured growing season rates for cattail and sawgrass of 4.1 and $5.9 \mathrm{~mm} \mathrm{day}^{-1}\left(\right.$ Mfabeni $\left.=3.2 \mathrm{~mm} \mathrm{day}^{-1}\right)$ and non-growing season rates of 2.2 and $2.0 \mathrm{~mm} \mathrm{day}^{-1}$ $\left(\right.$ Mfabeni $=1.8 \mathrm{~mm}_{\text {day }}{ }^{-1}$ ). The Mfabeni Mire ET is generally lower than at these other comparable wetland sites. This is likely due to the low leaf area, vapour pressure deficit and a net irradiance, which was suppressed at the Mfabeni Mire due to prevailing cloudy conditions especially during the summer (Figs. 5b and 6a).

The Priestley-Taylor model was originally derived for use over extensive, saturated surfaces. When $\alpha=1$, the equation represents the equilibrium model, which occurs when the gradient of VPD approaches zero and $\mathrm{ET}_{\mathrm{EQ}}$ equals potential evaporation. During unstable daytime conditions, this is mostly not the case. Priestley and Taylor (1972) found an average $\alpha$ over oceans and saturated land of 1.26. This implies that additional energy increases the ET by a factor of 1.26 over $\mathrm{ET}_{\mathrm{EQ}}$. This has been explained by some as a result of entrainment of warm, dry air, down through the convective boundary layer (Lhomme, 1997). Numerous studies have determined other values for $\alpha$ (Monteith, 1981; Paw and Gao, 1988; Clulow et al., 2012). Ingram (1983) found the value of $\alpha$ to be dependent on vegetation cover and that, for treeless bogs, $\alpha$ lies between 1 and 1.1 and for fens approximately 1.4. Mao et al. (2002) derived values for $\alpha$ in a subtropical region of Florida (USA) over sawgrass and cattail communities interspersed with open water areas of between 1.12 and 0.90 . Most available literature regarding suitable $\alpha$ values is, however, derived from studies in subarctic regions (Eaton et al., 2001), arid areas (Bidlake, 2000), over lakes (Rosenberry et al., 2007) or boreal aspen forest (Krishnan et al., 2006). The Priestley-Taylor $\alpha$ is site-specific and these estimates from the Mfabeni Mire for southern African vegetation and climatic conditions are valuable.

The $\alpha$ estimate of 1.0 (with an offset of $-0.3 \mathrm{~mm}$ ) calculated for the Mfabeni Mire is low in comparison with results from much of the international literature. However, it agrees well with those of Mao et al. (2002), German et al. (2000) and Abtew (1996) derived from the Florida (USA) Everglade wetlands, and very well with the estimate of 1.035 of Souch et al. (1996) during the warm summer climate of the Indiana Dunes National Lakeshore Great Marsh. In this study, it was also noted that a flow of humid air off the nearby Lake Michigan suppressed evaporation from the marsh. Equilibrium evaporation clearly describes the evaporation rate in the Mfabeni Mire and other wetlands of subtropical climates surrounded by open water or other wetland types.

The standardized FAO-56 Penman-Monteith model, together with a $K_{\mathrm{c}}$, was developed to be applied internationally allowing comparison between different sites in different locations (Allen et al., 1998, 2006). It has, in some respects, become the industry standard in terms of ET estimation from different land-uses and is incorporated into numerous hydrological models (ACRU, SWAT, SWAP) and would be a popular solution for a wetland ecologist or hydrologist seeking to characterize the ET from a wetland using meteorological inputs. The report by Allen et al. (1998) is comprehensive and provides solutions for different time steps and levels of data, increasing the accessibility of the method. The relatively poor relationship between $\mathrm{ET}_{\mathrm{SR}}$ and $\mathrm{ET}_{\mathrm{r}}\left(R^{2}=0.82\right)$, for the Mfabeni Mire, showed that, despite attempts to create 
a universal solution, it should be used with caution when applied to natural vegetation. An alternative to the $K_{\mathrm{c}}$ method is to estimate the ET using the Penman-Monteith method, but Drexel et al. (2004) found the lack of information on aerodynamic and surface resistances limiting.

The Priestley-Taylor model is a simplification of the FAO56 Penman-Monteith model in which the mass transfer term is reasoned to be close to zero over a wet expansive surface and is ignored. The residual variation around the regression between $\mathrm{ET}_{\mathrm{SR}}$ on $\mathrm{ET}_{\mathrm{r}}\left(R^{2}=0.82\right)$ was higher than between $\mathrm{ET}_{\mathrm{SR}}$ and $\mathrm{ET}_{\mathrm{EQ}}\left(R^{2}=0.94\right)$. This difference must therefore be introduced from within the mass transfer term of the FAO56 Penman-Monteith model, which is a function of wind speed and VPD (or air temperature and relative humidity). This relationship between $\mathrm{ET}_{\mathrm{SR}}$ and $\mathrm{ET}_{\mathrm{r}}$ is described by $K_{\mathrm{c}}$ (Eq. 4), which was most variable in October when the highest daily average wind speeds and lowest daily average VPDs were measured (Fig. 3). In contrast, the daily variability of $K_{\mathrm{c}}$ was lowest in February, which corresponded to the month with the lowest wind speed and highest VPD. The high wind speeds, possibly combined with low VPDs, reduced the confidence with which the FAO-56 Penman-Monteith model can be used to predict ET $_{\mathrm{SR}}$ at the Mfabeni Mire.

Leaf area index and albedo are important descriptors of a site in terms of ET. The albedo data are useful for future solar irradiance modelling studies and for remote sensing energy balance models such as the Surface Energy Balance Algorithm for Land (SEBAL) model, which has been used successfully in wetland areas (Bastiaanssen et al., 1998; Mohamed et al., 2006). Asner et al. (2003), in their global synthesis of LAI observations, concluded that the leaf area index of the wetland biome is not well represented internationally but that it is a key descriptor of vegetation. They document the results from six wetland studies resulting in a mean wetland LAI of 6.3 with a minimum of 2.5 and a maximum of 8.4. In comparison, the LAI of the Mfabeni Mire was lower, between $\sim 1.7$ in winter and $\sim 2.8$ in summer due to the narrow leaves of the vegetation. This result is of importance where site-specific parameters (such as the Priestley-Taylor $\alpha$ factor) are transferred to similar or nearby wetlands. Knowles (1996), for example, applied a correction to $K_{\mathrm{c}}$ based on an LAI that is lower than full canopy cover. The LAI is therefore an important determinant of $\mathrm{ET}_{\mathrm{SR}}$, and the relatively low $\mathrm{ET}_{\mathrm{SR}}$ in contrast to the $\mathrm{ET}_{\mathrm{r}}$ of the Mfabeni Mire could therefore partly be explained by the low LAI of the Mfabeni Mire.

\section{Conclusions}

The contribution of freshwater supply from the Mfabeni Mire to Lake St. Lucia during dry periods is important to the survival of certain plant and animal species in the iSimangaliso Wetland Park. This freshwater supply is mainly dependent on the variability of the major components of the water balance, namely rainfall and total evaporation (ET). Attempts to quantify the water balance have been limited through uncertainties in quantifying ET from the Mfabeni Mire. There are few measurements of ET from comparable wetlands in South Africa, and, despite advances in evaporation measurement and modelling from wetlands, there still exists some doubt as to which methods are best suited to characterise wetland ET, with most authors suggesting a combination of methods.

The SR method was successfully used to estimate $H$ and was found to be suitable for long-term, unattended use over a subtropical wetland with periodic calibration using eddy covariance. It therefore has the potential to become more accessible to wetland researchers, but the method is still relatively new and complete SR systems are not commercially available. Due to system complexity, it currently remains the domain of micrometeorologists.

Despite plentiful water and a subtropical environment, wetlands are not necessarily the high water users they are frequently perceived to be (Bullock and Acreman, 2003). Even high wind speeds characteristic of the site did not raise the ET due to the low evaporative demand (or VPD) of the air. Despite maximum ET rates of up to $6.0 \mathrm{~mm} \mathrm{day}^{-1}$, the average summer (October to March) ET $_{\mathrm{SR}}$ was lower $\left(3.2 \mathrm{~mm} \mathrm{day}^{-1}\right)$ due to intermittent cloud cover, which reduced the available energy. In winter (May to September), there was less cloud cover but the average ET $_{\mathrm{SR}}$ was only $1.8 \mathrm{~mm} \mathrm{day}^{-1}$ due to plant senescence, and the accumulated $\mathrm{ET}_{\mathrm{SR}}$ over 12 months was $900 \mathrm{~mm}$. The results compared well with studies in similar subtropical wetlands of the Northern Hemisphere, although they are slightly lower due to lower leaf areas.

The Embomveni Dune (terrestrial grassland) measurements of $\mathrm{ET}_{\mathrm{SR}}$ provided a useful contrast to the Mfabeni Mire (fen). The $\mathrm{ET}_{\mathrm{SR}}$ was seasonal at both sites yet only $478 \mathrm{~mm}$ over 12 months. Even for brief periods after rainfall when the soil water was not limited, the ET $_{\mathrm{SR}}$ was lower at the Embomveni Dune site. The vegetation has therefore adapted to dry conditions and has a low water-use requirement even with higher soil water availability. However, for the majority of the measurement period, the $\mathrm{ET}_{\mathrm{SR}}$ was limited by soil water availability. The drought conditions $(650 \mathrm{~mm}$ of rainfall versus a mean annual precipitation of $1200 \mathrm{~mm} \mathrm{yr}^{-1}$ ) therefore contributed to the low summer $\mathrm{ET}_{\mathrm{SR}}$ at the Embomveni Dunes, which is expected to be higher in a normal to high rainfall year.

A comparison of $\mathrm{ET}_{\mathrm{SR}}$ with $\mathrm{ET}_{\mathrm{r}}$ suggests that the crop factor approach was not suited to estimating $\mathrm{ET}_{\mathrm{SR}}$ for the Mfabeni Mire. The Priestley-Taylor model, however, closely reflected the daily changes in $\mathrm{ET}_{\mathrm{SR}}$ at the Mfabeni Mire, and $\alpha=1$ (intercept of -0.3 ) can be used with confidence to estimate daily ET $\left(R^{2}=0.96\right)$ throughout the year. This relationship between $\mathrm{ET}_{\mathrm{SR}}$ and $\mathrm{ET}_{\mathrm{EQ}}$ showed that $\mathrm{ET}$ from the Mfabeni Mire was largely dependent on energy and was at the equilibrium (or potential) rate. Including the mass 
transfer term, as is the case in the FAO-56 Penman-Monteith model, was of no benefit due to the complexity of the high wind speed and low VPD at the site.

The significant advantage of the Priestley-Taylor method for use by wetland hydrologists and ecologists is the low data requirement. If $R_{\mathrm{n}}$ and $G$ are measured or estimated (Drexler et al., 2004) from a nearby weather station, then only $T_{\max }$ and $T_{\min }$ are required to estimate the wetland daily ET. In addition, the Priestley-Taylor model has been internationally accepted and tested since 1972, although the extent to which it can be applied beyond the Mfabeni Mire to other South African wetlands under equilibrium conditions requires further investigation.

The ET measurements and modelling guidelines for the Mfabeni Mire and Embomveni Dunes will assist in determining a more accurate water balance, which was previously impossible without reliable estimates of ET. This will not only reduce uncertainty in water-balance studies and environmental flow determinations but provide better insight into the resilience of the system to droughts and the pressures of climate change.

Acknowledgements. The research presented in this paper forms part of an unsolicited research project (Evapotranspiration from the Nkazana Swamp Forest and Mfabeni Mire) that was initiated by the Water Research Commission (WRC) of South Africa in Key Strategic Area 2 (i.e. Water-Linked Ecosystems). The project is managed and funded by the WRC, with co-funding provided by the Council for Scientific and Industrial Research. The iSimangaliso Wetland Park are acknowledged for their support in providing access to the research sites. Ab Grootjans and Althea Grundling were instrumental in initiating this work and sharing information. Mike Savage provided invaluable expertise in the flux measurements and processing and Craig Morris provided statistical support. Assistance in the field by Siphiwe Mfeka, Alecia Nickless, Scott Ketcheson, Joshua Xaba and Lelethu Sinuka is much appreciated. The support provided by Erwin Sieben, Bikila Dullo and Mathilde Luïse was also invaluable.

Edited by: A. Ghadouani

\section{References}

Abtew, W.: Evapotranspiration measurements and modeling for three wetland systems in south Florida, J. Am. Water Resour. As., 32, 465-473, 1996.

Acreman, M. C., Harding, R. J., Lloyd, C. R., and McNeil, D. D.: Evaporation characteristics of wetlands: experience from a wetgrassland and a reedbed using eddy correlation measurements, Hydrol. Earth Syst. Sci., 7, 11-21, doi:10.5194/hess-7-11-2003, 2003.

Allen, R. G., Pereira, L. S., Raes, D., and Smith, M.: Crop evapotranspiration: Guidelines for computing crop water requirements, FAO Irrigation and Drainage Paper 56, Food and Agriculture Organization of the United Nations, Rome, Italy, 1998.
Allen, R. G., Pruitt, W. O., Wright, J. L., Howell, T. A., Ventura, F., Snyder, R., Itenfisu, D., Steduto, P., Berengena, J., Yrisarry, J. B., Smith, M., Pereira, L. S., Raes, D., Perrier, A., Alves, I., Walter, I., and Elliot, R.: A recommendation on standardized surface resistance for hourly calculation of reference $\mathrm{ET}_{o}$ by the FAO56 Penman-Monteith method, Agr. Water Manage., 81, 1-22, 2006.

Annandale, J. G., Jovanovic, N. Z., Campbell, G. S., du Sautoy, N., and Benade, N.: A two-dimensional water balance model for micro-irrigated hedgerow tree crops, Irrigation Sci., 22, 157 170, 2003.

Asner, G. P., Scurlock, J. M. O., and Hicke, J. A.: Global synthesis of leaf area index observations: implications for ecological and remote sensing studies, Global Ecol. Biogeogr., 12, 191-205, 2003.

Baldocchi, D.: A comparative study of mass and energy exchange rates over a closed C3 (wheat) and an open C4 (corn) crop: II. $\mathrm{CO}_{2}$ exchange and water use efficiency, Agr. Forest Meteorol., 67, 291-321, 1994.

Bastiaanssen, W. G. M., Menenti, M., Feddes, R. A., and Holtslang, A. A.: A remote sensing surface energy balance algorithm for land (SEBAL): 1. Formulation, J. Hydrol., 212, 198-212, 1998.

Bidlake, W. R.: Evapotranspiration from a bulrush-dominated wetland in the Klamath Basin, Oregon, J. Am. Water Resour. As., 36, 1309-1320, 2000.

Birkhead, A. L., James, C. S., and Kleynhans, M. T.: Hydrological and hydraulic modeling of the Nyl River floodplain - Part 2: Modelling hydraulic behavior, Water SA, 33, 9-20, 2007.

Bjørkenes, M., Haldorsen, S., Mulder, J., Kelbe, B., and Ellery, F.: Baseline groundwater quality in the coastal aquifer of St. Lucia, South Africa, in: Proceedings of the NATO Advance Study Institute on Management and Sustainable Development of Urban Groundwater Systems, edited by: Tellam, J. H., Rivett, M. O., and Israfilov, R. G., Springer, Netherlands, 233-240, 2006.

Bouchet, R. J.: Evapotranspiration reelle et potentielle, signification climatique, International Association of Scientific Hydrology Publication, 62, 134-142, 1963.

Bullock, A. and Acreman, M.: The role of wetlands in the hydrological cycle, Hydrol. Earth Syst. Sci., 7, 358-389, doi:10.5194/hess-7-358-2003, 2003.

Cade, B. S., Terrell, J. W., and Schroeder, R. L.: Estimating effects of limiting factors with regression quantiles, Ecology, 80, 311323, 1999.

Chapman, R. A.: Determination and modeling of evapotranspiration from wetlands, M.Sc. thesis, University of Natal, Pietermaritzburg, South Africa, 147 pp., 1990.

Clulow, A. D., Everson, C. S., and Gush, M. B.: The long-term impact of Acacia mearnsii trees on evaporation, streamflow and ground water resources, Water Research Commission Report No. TT505/11, ISBN 978-1-4312-0020-3, Water Research Commission, Pretoria, South Africa, 104 pp., 2012.

Drexler, J. Z., Snyder, R. L., Spano, D., and Paw U, K. T.: A review of models and micrometeorological methods used to estimate wetland evapotranspiration, Hydrol. Process., 18, 20712101, 2004.

Dye, P. J., Jarmain, C., le Maitre, D., Everson, C. S., Gush, M., and Clulow, A.: Modelling vegetation water use for general application in different categories of vegetation, Water Research Commission Report No. 13119/1/08, ISBN 978-1-77005-559-9, Water Research Commission, Pretoria, South Africa, 156 pp., 2008. 
Eaton, A. K., Rouse, W. R., Lafleur, P. M., Marsh, P., and Blanken, P. D.: Surface energy balance of the western and central Canadian subarctic: Variations in the energy balance among five major terrain types, J. Climate, 14, 3692-3703, 2001.

Everson, C. S., Molefe, G. L., and Everson, T. M.: Monitoring and modelling components of the water balance in a grassland catchment in the summer rainfall area of South Africa, Water Research Commission Report No. 493/1/98, ISBN 1-86845-443-6, Water Research Commission, Pretoria, South Africa, 138 pp., 1998.

Everson, C. S., Burger, C., Olbrich, B. W., and Gush, M. B.: Verification of estimates of water use from riverine vegetation on the Sabie river in the Kruger National park, Water Research Commission Report No. 877/1/01, ISBN 1-86845-781-8, Water Research Commission, Pretoria, South Africa, 88 pp., 2001.

Everson, C. S., Everson, T. M., and Mthembu, B. E.: Effect of agroforestry and intercropping systems on fodder production, Water Research Commission Report No. 1351/1/12, ISBN 9781-4312-0258-0, Water Research Commission, Pretoria, South Africa, 121 pp., 2012.

Everson, C. S., Clulow, A. D., and Memgistu, M.: Feasiblity study on the determination of riparian evaporation in non-perenial systems, Water Research Commission Report No. TT424/09, ISBN 978-1-77005-905-4, Water Research Commission, Pretoria, South Africa, 38 pp., 2009.

Fujieda, M., Kudoh, T., de Cicco, V., and de Calvarcho, J. L.: Hydrological processes at two subtropical forest catchments: the Serra do Mar, São Paulo, Brazil, J. Hydrol., 196, 26-46, 1997.

Gao, W., Shaw, R. H., and Paw U, K. T.: Observation of organized structure in turbulent flow within and above a forest canopy, Bound.-Lay. Meteorol., 47, 349-377, 1989.

German, E. R.: Regional evaluation of evapotranspiration in the Everglades, USGS, Water-Resources Investigations Report 004217, Tallahassee, Florida, United States of America, 2000.

Goulden, M. L., Litvak, M., and Miller, S. D.: Factors that control Typha marsh evapotranspiration, Aquat. Bot., 86, 97-106, 2007.

Grundling, P.-L., Mazus, H., and Baartman, L.: Peat resources in northern KwaZulu-Natal wetlands: Maputaland, Department of Environmental Affairs and Tourism Pretoria, South Africa, 102 pp., 1998.

Headley, T. R., Davison, L., Huett, D. O., and Müller, R.: Evapotranspiration from subsurface horizontal flow wetlands planted with Phragmites australis in sub-tropical Australia, Water Res., 46, 345-354, 2012.

Inman-Bamber, N. B.: A growth model for sugarcane based on a simple carbon balance and the CERES-Maize water balance, $\mathrm{S}$. Afr. J. Plant Soil, 8, 93-99, 1991.

Ingram, H. A. P.: Hydrology, in: Mires: Swamp, Bog, Fen and Moor, edited by: Gore, A. J. P., Elsevier, New York, 67-158, 1983.

Jacobs, J., Mergelsberg, S., Lopera, A., and Myers, D.: Evapotranspiration from a wet prairie wetland under drought conditions: Paynes prairie preserve, Florida, USA, Wetlands, 22, 374-385, 2002.

Jarmain, C., Everson, C. S., Savage, M. J., Mengistu, M. G., Clulow, A. D., Walker, S., and Gush, M. B.: Refining tools for evaporation monitoring in support of water resources management, Water Research Commission Report No. 1567/1/08, ISBN 9781-77005-798-2, Water Research Commission, Pretoria, South Africa, 137 pp., 2009.
Kaimal, J. C. and Finnigan, J. J.: Atmospheric Boundary Layer Flows: Their Structure and Measurement, Oxford University Press, New York, 304 pp., 1994.

Knowles Jr., L.: Estimation of evapotranspiration in the Rainbow Springs and Silver Springs Basins in north-central Florida, US, Geological Survey Water-Resources Investigations Report 964024, United States of America, 1996.

Kotze, D. C. and Breen, C. M.: WETLAND-USE: A wetland management decision support system for South African freshwater palustrine wetlands, Department of Environmental Affairs and Tourism, Pretoria, South Africa, 2000.

Krishnan, P., Black, T. A., Grant, N. J., Barr, A. G., Hogg, E. T. H., Jassal, R. S., and Morgenstern, K.: Impact of changing soil moisture distribution on net ecosystem productivity of a boreal aspen forest during and following drought, Agr. Forest Meteorol., 139, 208-223, 2006.

Lhomme, J. P.: An examination of the Priestley-Taylor equation using a convective boundary layer model, Water Resour. Res., 33, 2571-2578, 1997.

Lubke, R. A., Avis, A. M. and Phillipson, P. B.: Vegetation and Floristics, Chapter 7, in: Coastal and environmental services, Environmental Impact Assessment-Eastern Shores of Lake St Lucia (Kingsa/Tojan Lease Area), Specialist reports, Vol. 1, Biophysical environment, Rhodes University, Grahamstown, South Africa, 1992.

Mao, L. M., Bergman, M. J., and Tai, C. C.: Evapotranspiration measurement and estimation of three wetland environments in the upper St. Johns River Basin, Florida, J. Am. Water Resour. As., 38, 1271-1285, 2002.

Mengistu, M. G. and Savage M. J.: Surface renewal method for estimating sensible heat flux, Water SA, 36, 9-18, 2010.

Midgley, D. C., Pitman, W. V., and Middleton, B. J: Surface water resources of South Africa 1990 (Vol. 1 to 6), Water Research Commission Report No's. 298/1.1/94 to 298/6.1/94 (text) and 298/1.2/94 to 298/6.2/94 (maps), Water Research Commission, Pretoria, South Africa, 1994.

Mohamed, Y. A., Savenije, H. H. G., Bastiaanssen, W. G. M., and van den Hurk, B. J .J. M.: New lessons on the Sudd hydrology learned from remote sensing and climate modeling, Hydrol. Earth Syst. Sci., 10, 507-518, doi:10.5194/hess-10-507-2006, 2006.

Monteith, J. L.: Dew, Q. J. Roy. Meteorol. Soc., 83, 322-341, 1957.

Monteith, J. L.: Evaporation and environment: the state and movement of water in living organisms, Symp. Soc. Exp. Biol., 19, 205-234, 1965.

Monteith, J. L.: Evaporation and surface temperature, Q. J. Roy. Meteor. Soc., 107, 1-27, 1981.

Mucina, L. and Rutherford, M. C. (Eds.): The Vegetation of South Africa, Lesotho and Swaziland, Strelitzia 19, South African National Biodiversity Institute, Pretoria, South Africa, 2006.

Paw U, K. T. and Brunet, Y.: A surface renewal measure of sensible heat flux density, Proc. 20th Conf. Agric. For. Meteorol, 1013 September 1991, Salt Lake City, UT, Ame. Meteorol. Soc., Boston, MA, 52-53, 1991.

Paw U, K. T. and Gao, W.: Applications of solutions to non-linear energy budget equations, Agr. Forest Meteorol., 43, 121-145, 1988.

Paw U, K. T., Brunet, Y., Collineau, S., Shaw, R. H., Maitani, T., Qiu, J., and Hipps, L.: On coherent structures in turbulence above 
and within agricultural plant canopies, Agr. Forest Meteorol., 61, 55-68, 1992.

Paw U, K. T., Qui, J., Su, H. B., Watanabe, T., and Brunet, Y.: Surface renewal analysis: a new method to obtain scalar fluxes, Agr. Forest. Meteorol., 74, 119-137, 1995.

Paw U, K. T., Snyder, R. L., Spano, D., and Su, H. B.: Surface renewal estimates of scalar exchange, in: Micrometeorology in Agricultural Systems, edited by: Hatfield, J. L. and Baker, J. M., Agronomy Monograph, 47, 455-483, 2005.

Penman, H. L.: Natural Evaporation from Open Water, Bare Soil and Grass, P. Roy. Soc. Lond. A Mat., 193, 120-145, 1948.

Price, J. S.: Blanket bog in Newfoundland: Part 2, Hydrological processes, J. Hydrol., 135, 103-119, 1992.

Priestley, C. H. B. and Taylor, R. J.: On the Assessment of Surface Heat Flux and Evaporation Using Large-Scale Parameters, Mon. Weather Rev., 100, 81-92, 1972.

Raupach, M. R., Finnigan, J. J., and Brunei, Y.: Coherent eddies and turbulence in vegetation canopies: The mixing-layer analogy, Bound.-Lay. Meteorol., 78, 351-382, 1996.

Rosenberry, D. O., Winter, T. C., Buso, D. C., and Likens, G. E.: Comparison of 15 evaporation methods applied to a small mountain lake in the northeastern USA, J. Hydrol., 340, 149-166, 2007.

Savage, M. J., Everson, C. S., and Metelerkamp, B. R.: Evaporation measurement above vegetated surfaces using micrometeorological techniques. Water Research Commission Report No. 349/1/97, ISBN 1-86845 363 4, Water Research Commission, Pretoria, South Africa, 248 pp., 1997.

Savage, M. J., Everson, C. S., Odhiambo, G. O., Mengistu, M. G., and Jarmain, C.: Theory and practice of evaporation measurement, with a special focus on SLS as an operational tool for the estimation of spatially-averaged evaporation, Water Research Commission Report No. 1335/1/04, ISBN 1-77005-247-X, Pretoria, South Africa, 204 pp., 2004.

Schulze, R. E.: Hydrology and agrohydrology: A text to accompany the ACRU 3.00 agrohydrological modelling system, Water Research Commission Report No. TT 69/9/95, Water Research Commission, Pretoria, South Africa, 1995.

Schulze, R. E., Maharaj, M., Lynch, S. D., Howe, B. J., and MelvilTomson, B.: South African atlas of agrohydrology and climatology, Water Research Commission Report No. TT 82/96, Water Research Commission, Pretoria, South Africa, 1997.

Smithers, J. C., Donkin, A. D., Lorentz, S. A., and Schulze, R. E.: Uncertainties in estimating evaporation and the water budget of a southern African wetland, Man's influence on freshwater ecosystems and water use (Proceedings of a Boulder Symposium, July 1995), IAHS-AISH P., 230, 103-113, 1995.

Snyder, R. L., Spano, D., and Paw U, K. T.: Surface renewal analysis for sensible heat and latent heat flux density, Bound.-Lay. Meteorol., 77, 249-266, 1996.

Sokolic, F.: The use of satellite remote sensing to determine the spatial and temporal distribution of surface water on the Eastern Shores of Lake St Lucia, MSc thesis, School of Environmental Sciences, University of KwaZulu-Natal, South Africa, 2006.
Souch, C., Wolfe, C. P., and Grimmtind, C. S. B.: Wetland evaporation and energy partitioning: Indiana Dunes National Lakeshore, J. Hydrol., 184, 189-208, 1996.

Spano, D., Snyder, R. L., Duce, P., and Paw U, K. T.: Estimating sensible and latent heat flux densities from grapevine canopies using surface renewal, Agr. Forest Meteorol., 104, 171-183, 2000.

Tanner, C. B.: Energy balance approach to evapotranspiration from crops, Soil Sci. Soc. Am. Pro., 24, 1-9, 1960.

Tanner, C. B. and Thurtell, G. W.: Anemoclinometer measurement of Reynolds stress and heat transport in the atmosphere surface layer, Final Report, United States Army Electrnoics Command, Atmospheric Sciences Laboratory, Fort Huachuca, Arizona, 1969.

Taylor, R., Adams, J. B., and Haldorsen, S.: Primary habitats of the St Lucia Estuarine System, South Africa, and their responses to mouth management, Afr. J. Aquat. Sci., 31, 31-41, 2006 a.

Taylor, R., Kelbe, B., Haldorsen, S., Botha, G. A., Wejden, B., Vaeret, L., and Simonsen, M. B.: Groundwater-dependent ecology of the shoreline of the subtropical Lake St Lucia estuary, Environ. Geol., 49, 586-600, 2006b.

Thom, A. S.: Momentum, mass and heat exchange in plant communities, in: Vegetation and the Atmosphere, Vol. 1, Principals, edited by: Monteith, J. L., Acad. Press., London, 57-109, 1975.

Vaeret, L. and Sokolic, F.: Methods for studying the distribution of groundwater-dependent wetlands: a case study from Eastern Shores, St Lucia, South Africa, in: Responses to global change and management actions in coastal groundwater resources, edited by: Været, L., Maputaland, southeast Africa, PhD Thesis, Norwegian University of Life Sciences, Norway, 2008.

Van Atta, C. W.: Effect of coherent structures on structure functions of temperature in the atmospheric boundary layer, Arch. Mech, 29, 161-171, 1977.

Van Heerden, P. S., Crosby, C. T., Grové, B., Benadé, N., Theron, E., Schulze, R. E., and Tewolde, M. H.: Integrating and updating of SAPWAT and PLANWAT to create a powerful and userfriendly irrigation planning tool, Water Research Commission Report No. TT 391/08, ISBN 978-1-77005-828-6, Water Research Commission, Pretoria, South Africa, 2009.

Vrdoljak, S. M. and Hart, R. C.: Groundwater seeps as potentially important refugia for freshwater fishes on the Eastern Shores of Lake St Lucia, KwaZulu-Natal, South Africa, Afr. J. of Aquat. Sci., 32, 125-132, 2007.

VSN International: GenStat for Windows 14th Edition, VSN International, Hemel Hempstead, United Kingdom, 2011.

Webb, E. K., Pearman, G. I., and Leuning, R.: Correction of flux measurements for density effects due to heat and water vapour transfer, Q. J. Roy. Meteorol. Soc., 106, 85-100, 1980.

Whitfield, A. K. and Taylor, R. H.: A review of the importance of freshwater inflow to the future conservation of Lake St Lucia, Aquat. Conserv., 19, 838-848, 2009. 